\title{
Seasonal occurrence of diseases in a recirculation system for salmonid fish in the Czech Republic
}

\author{
Miroslava Palíková ${ }^{1}$, Stanislav Navrátil ${ }^{1}$, Alois Č́í̌ek², Zdeňka Soukupová1, \\ Štěpán Lang ${ }^{3}$, Radovan Kopp ${ }^{3}$, Jan Mareš ${ }^{3}$ \\ ${ }^{1}$ University of Veterinary and Pharmaceutical Sciences Brno, Faculty of Veterinary Hygiene and Ecology, \\ Department of Ecology and Diseases of Game, Fish and Bees, ${ }^{2}$ Faculty of Veterinary Medicine, \\ Department of Infectious Diseases and Microbiology, Brno, Czech Republic \\ ${ }^{3}$ Mendel University, Faculty of Agronomy, Department of Zoology, Fisheries, Hydrobiology and Apiculture, \\ Brno, Czech Republic \\ Received January 30, 2014 \\ Accepted May 28, 2014
}

\begin{abstract}
Aquaculture represents the fastest growing animal husbandry in many countries. However, higher intensity of fish farming can pose higher health hazards, too. We monitored the health status of fish from one fish farm in South Bohemia and discovered the main health problems in the breeding. For two years we examined a total of 224 specimens of brook trout (Salvelinus fontinalis), 126 specimens of hybrids $(S$. fontinalis $\times S$. alpinus), 49 specimens of rainbow trout (Oncorhynchus mykiss) - all clinically healthy, and 100 clinically diseased or freshly dead fish. We registered skin erosions mainly in the caudal peduncle and tail fin. Two parasite species were identified (one protist Ichthyophthirius multifiliis and one nematode Raphidascaris acus) by parasitological examination. The epidemiological indicators of I. multifiliis were low. The prevalence of adult $R$. acus was $0-86 \%$ with a maximum in June. From November, capsules with larval stages of $R$. acus appeared in internal organs. Their highest intensity (200 pieces) and prevalence $(100 \%)$ were detected in October. By microbiological examination of skin and gills, we identified changes in the density of bacterial population and its species composition dependent on water temperature and fish density. The most important problem on the monitored fish farm seems to be furunculosis of salmonid fish in all clinical forms, and the high intensity of larval stages of $R$. acus. The originality of this study is based on the fact that the observed breeding employs the first Danish recirculation system in the Czech Republic and no recent information about health problems has been available.
\end{abstract}

Furunculosis, Ichthyophthirius multifiliis, Nematoda, Raphidascaris acus

Over $45 \%$ of the increasing world fish consumption is covered by aquaculture production (FAO 2010). Efforts to reduce the burden on the water environment caused by intensive fish farming and dependence on abundant source of safe clean water have led to the development of recirculating aquaculture systems (Martins et al. 2010). One type of recirculating system involves the use of 'Danish technology' based on the utilization of airlifts providing water circulation and gas exchange. The development of Danish recirculating systems for salmonid fish productions is based mainly on the need for an effective use of good quality pathogen-free water, improved utilization of feed, and a reduction of the burden on the waste water environment (Jokumsen and Swendsen 2010).

The aim of this study was to find the presence and dynamics of diseases in the recirculation systems of fish of different origin and densities, dependent on the season.

\section{Materials and Methods}

There are two functional farms with the Danish type recirculation systems in the Czech Republic. We conducted our monitoring at a farm where Oncorhynchus mykiss, Salvelinus fontinalis and hybrids of $S$. fontinalis and S. alpinus are reared. Non-salmonid fishes were absent there. The overall water volume of the observed farm 
is $1000 \mathrm{~m}^{3}$. The system comprises 12 rearing channels, each with a volume of about $34 \mathrm{~m}^{3}$, and two types of water treatment units (biofilters): one with floating elements and the other with sinking elements. There is an area with diffusers to aerate the water and get rid of $\mathrm{CO}_{2}$ and a $4.5 \mathrm{~m}$ deep airlift - the engine for water circulation behind the biofilters. All rearing channels have their own diffusers.

The farm is located in the highlands, near the town of Kamenice nad Lipou, nearly 600 metres above sea level $\left(15.0946147^{\circ} \mathrm{E}, 49.3194111^{\circ} \mathrm{N}\right)$. Sources of water include drilled underground water or streams from nearby woods.

Two collections of fish from stock to marketable size were examined during the monitoring. The first collection was examined from May 2012 to March 2013, and the second one from May to October 2013.

From May 2012 to March 2013 we examined fish from four selected channels: 175 specimens of brook trout (S. fontinalis) from two places of origin (signed $\mathrm{S}$ or $\mathrm{N}$ ), and 77 specimens of hybrids $(S$. fontinalis $\times S$. alpinus). Salvelinus fontinalis (N) was reared in two different fish densities: 550 or 270 (i.e. $1 / 2$ fish density) specimens per $\mathrm{m}^{3}$. Salvelinus fontinalis $(\mathrm{S})$ and the hybrids were reared in a fish density of 550 and $270(1 / 2)$ specimens per $\mathrm{m}^{3}$, respectively. The initial weight and total body length of fish was: $96 \pm 20 \mathrm{~g}$ and $202.3 \pm 18.9 \mathrm{~mm}$ in brook trout $(\mathrm{S}), 110.4 \pm 26.3 \mathrm{~g}$ and $210.6 \pm 14.8 \mathrm{~mm}$ in brook trout $(\mathrm{N})$, and $168.1 \pm 29.0 \mathrm{~g}$ and $256.6 \pm 12.9 \mathrm{~mm}$ in hybrids (mean $\pm \mathrm{SD}$ ).

From May to November 2013 we examined fish from three selected channels: 49 specimens of brook trout (S. fontinalis S), 49 specimens of hybrids, and 49 specimens of rainbow trout (Oncorhynchus mykiss). All fish were reared in a fish density of 440 specimens per $\mathrm{m}^{3}$. The initial weight and total body length of fish was: $80.4 \pm$ $17.0 \mathrm{~g}$ and $194.3 \pm 13.3 \mathrm{~mm}$ in brook trout $(\mathrm{S}), 55.1 \pm 12.2 \mathrm{~g}$ and $185.4 \pm 14.3 \mathrm{~mm}$ in hybrids and $62.4 \pm 14.0 \mathrm{~g}$ and $188.4 \pm 15.7 \mathrm{~mm}$ rainbow trout (mean $\pm \mathrm{SD})$.

Seven fish from each of the selected channels were taken monthly. The fish were clinically examined, killed, measured, weighed and patho-morphologically (in indicated case also histologically), parasitologically, and microbiologically examined. The whole amount of examined fish was almost 400 clinically health and 100 clinically diseased or freshly dead fish. The influence of season, fish origin and fish density in brook trout was observed. Fish were fed extruded feed mixture for salmonid fish (Biomar, Denmark).

Smears from skin and gills for microscopic examination were made from the whole left half of the body and from two left gill-arches. The intensity of parasite infection is given in absolute numbers of nematods and capsules with nematode larvae, and in numbers of protists in the visual field of microscope at $\times 100$ magnification. Prevalence is given as the percentage of infected host individuals in each sample.

Samples of liver and intestine of some fish were collected and placed in $10 \%$ buffered formalin during necropsy. They were treated using a routine histological technique and embedded in paraffin. Sections of $5 \mu \mathrm{m}$ thickness were made from the paraffin blocks and stained with haematoxylin and eosin. The samples were then screened and photographed using an Olympus BX 51.

From May 2012 to March 2013 the skin and gills of clinically healthy fish were examined microbiologically. Microbiological examination was done as follows: skin and gill smears were carried to the laboratory in the Carry Blair transport media (Oxoid, UK) and immediately cultivated on Columbia blood agar (Oxoid, UK) and Anacker and Ordal agar (Anacker and Ordal 1955). Inoculated agar plates were incubated at $18{ }^{\circ} \mathrm{C}$ for $2-5$ days and periodically evaluated. The density of bacterial growth was expressed in the range of 1-4 according to the percentage of bacterial growth on the agar surface $(25,50,75,100 \%)$. Moreover, we also examined microbiologically 100 clinically diseased or freshly dead fish. Eight to ten fish were examined monthly from May 2012 to March 2013. Samples of kidney, liver, spleen and intestine were cultivated on the above mentioned media and incubated under the same conditions.

Water temperature during the monitored period is presented in Fig. 1.

\section{Results}

During patho-morphological examination of the fish examined from May 2012 to March 2013 we found various changes on the surface of fish in the form of grey erosions mainly around the dorsal and caudal fins which later showed secondary fungal infections. Sometimes we detected the presence of boil-like lesions in the centre of the erosion typical of a chronic form of furunculosis and sometimes we detected soft bumps. Moreover, in S. fontinalis examined from May to November 2013, further pathomorphological changes such as ascites, adhesions between organs and haemorrhages in liver started to appear in the autumn months. These pathomorphological findings were connected with the presence of a high amount of capsules with the larval stages of $R$. acus in the internal organs. The capsules were observed in the intestinal wall, between the pyloric appendages, and on the surface of the liver. Viable larvae were detected histologically in the intestinal wall (Plate II, Fig. 2) and in the liver parenchyma (Plate II, Fig. 3). The larvae involved inflammatory reaction and the development of typical granulomatous lesions. 


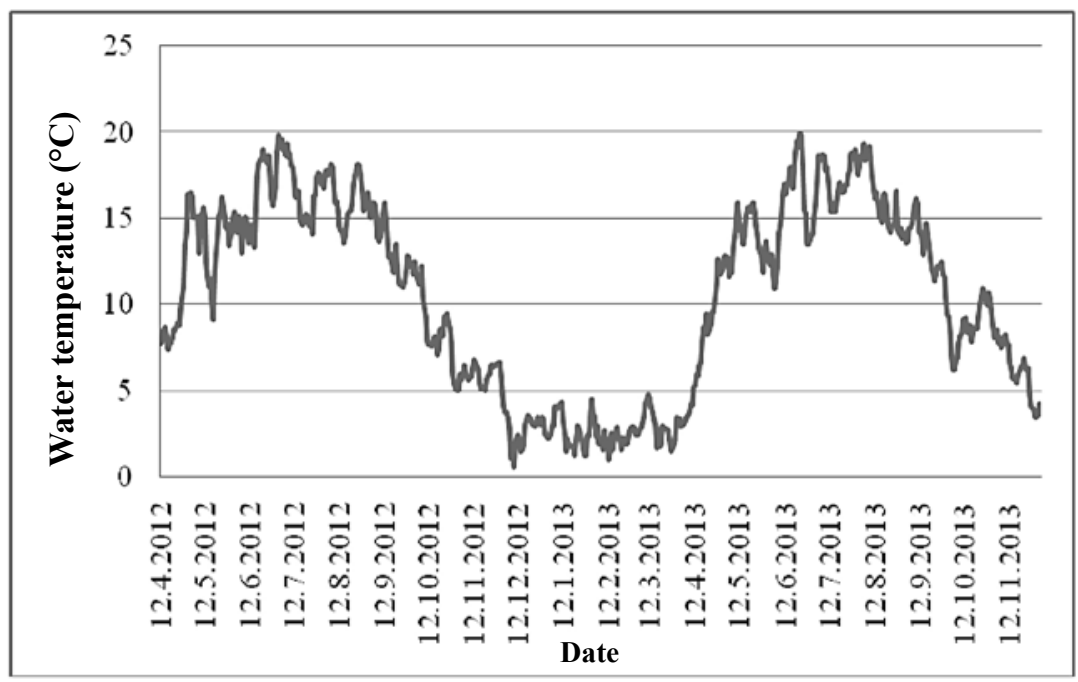

Fig. 1. Water temperature during the monitored period

Table 1. Intensity and prevalence of Ichthyophthirius multifiliis in examined fish.

\begin{tabular}{|c|c|c|c|c|}
\hline & $\begin{array}{c}\text { Salvelinus } \\
\text { fontinalis } \mathrm{S}\end{array}$ & $\begin{array}{c}\text { Salvelinus } \\
\text { fontinalis } \mathrm{N}\end{array}$ & Hybrids $1 / 2$ & $\begin{array}{c}\text { Salvelinus } \\
\text { fontinalis N } 1 / 2\end{array}$ \\
\hline June 2012 & 0 & 0 & skin $0-1 ; 43 \%$ & 0 \\
\hline July 2012 & 0 & 0 & skin $0-2 ; 29 \%$ & skin $0-2 ; 14 \%$ \\
\hline August 2012 & skin $0-1 ; 43 \%$ & 0 & skin $0-4 ; 57 \%$ & 0 \\
\hline \multirow[t]{2}{*}{ September 2012} & skin $0-2 ; 25 \%$ & skin $0-1 ; 57 \%$ & skin $0-4 ; 86 \%$ & skin $0-2 ; 43 \%$ \\
\hline & gills $0-1 ; 25 \%$ & gills $0-1 ; 14 \%$ & & \\
\hline \multirow[t]{2}{*}{ October 2012} & skin $0-4 ; 86 \%$ & skin $0-2 ; 71 \%$ & skin $0-2 ; 43 \%$ & - \\
\hline & gills $0-1 ; 43 \%$ & gills $0-2 ; 86 \%$ & & \\
\hline \multirow[t]{2}{*}{ November 2012} & skin $0-1 ; 43 \%$ & skin $0-2 ; 29 \%$ & 0 & - \\
\hline & gills $0-1 ; 14 \%$ & gills $0-2 ; 29 \%$ & & \\
\hline \multirow[t]{2}{*}{ December 2012} & 0 & skin $0-2 ; 25 \%$ & skin $0-1 ; 14 \%$ & - \\
\hline & & gills $0-1 ; 25 \%$ & & \\
\hline January 2013 & 0 & skin $0-1 ; 29 \%$ & skin $0-1 ; 14 \%$ & - \\
\hline
\end{tabular}

By parasitological examination we detected only two parasite species. The first parasite was Ichthyophthirius multifiliis on the skin and gills of the fish. The prevalence and intensity of this protist is presented in Table 1 . The finding of this parasite was very sporadic in 2013. The second parasite was the well-known Raphidascaris acus, first detected as adults in the cranial intestine. The highest prevalence of adult nematodes was found in brook trout but their intensity was low in 2012 (Table 2). In hybrids and in brook trout in low fish density we discovered adults sporadically. During November 2012 the presence of capsules with larvae of R. acus started appearing (Table 3). Tables 4 and 5 show that the maximal epidemiologic characteristics of adult nematodes in 2013 were already detected in June, and capsules were even detected in August which was about 2-3 months earlier than in 2012, and their numbers were higher than in 2012. 
Table 2. Intensity and prevalence of adult nematodes Raphidascaris acus from fish examined from May 2012 to March 2013.

\begin{tabular}{|c|c|c|c|c|}
\hline & $\begin{array}{c}\text { Salvelinus } \\
\text { fontinalis } \mathrm{S}\end{array}$ & $\begin{array}{c}\text { Salvelinus } \\
\text { fontinalis } \mathrm{N}\end{array}$ & Hybrids $1 / 2$ & $\begin{array}{c}\text { Salvelinus } \\
\text { fontinalis N } 1 / 2\end{array}$ \\
\hline May 2012 & 0 & $2 ; 14 \%$ & 0 & 0 \\
\hline June 2012 & 0 & $2 ; 14 \%$ & $1 ; 14 \%$ & $1 ; 14 \%$ \\
\hline July 2012 & 0 & $1 ; 29 \%$ & 0 & 0 \\
\hline August 2012 & 0 & 0 & $4 ; 14 \%$ & 0 \\
\hline September 2012 & $1 ; 38 \%$ & $1-2(\varnothing 1) ; 71 \%$ & 0 & 2 and $3 ; 29 \%$ \\
\hline October 2012 & $2 ; 14 \%$ & $1-5(\varnothing 2) ; 57 \%$ & 0 & - \\
\hline November 2012 & $1 ; 14 \%$ & $1 ; 14 \%$ & $1 ; 14 \%$ & - \\
\hline
\end{tabular}

$1 / 2$ - half fish density

Table 3. Intensity and prevalence of capsules with larvae Raphidascaris acus on internal organs of fish examined from May 2012 to March 2013.

\begin{tabular}{lccc}
\hline & Salvelinus fontinalis S & Salvelinus fontinalis N & Hybrids $1 / 2$ \\
\hline November 2012 & $2-100(\varnothing 30) ; 86 \%$ & $1-35(\varnothing 14) ; 71 \%$ & 0 \\
December 2012 & $1-30(\varnothing 9) ; 86 \%$ & $2-10(\varnothing 5) ; 62 \%$ & $20 ; 14 \%$ \\
January 2013 & $7-50(\varnothing 25) ; 100 \%$ & $6-22(\varnothing 11) ; 100 \%$ & $1-14 ;(\varnothing 5) ; 57 \%$ \\
February 2013 & $1-30(\varnothing 21) ; 50 \%$ & - & $1-2(\varnothing 2) ; 50 \%$ \\
March 2013 & $1-30(\varnothing 11) ; 62 \%$ & - & $1-10(\varnothing 5) ; 50 \%$ \\
\hline
\end{tabular}

$1 / 2$ - half fish density

Table 4. Intensity and prevalence of adult nematodes Raphidascaris acus from fish examined from May to November 2013.

\begin{tabular}{lccc}
\hline & Salvelinus fontinalis $S$ & Hybrids & Oncorhynchus mykiss \\
\hline May 2013 & 0 & $1-2(\varnothing 2) ; 43 \%$ & 1 and $8 ; 29 \%$ \\
June 2013 & $1-36(\varnothing 14) ; 86 \%$ & $2 ; 14 \%$ & $6-37(\varnothing 18) ; 86 \%$ \\
July 2013 & $1 ; 14 \%$ & 0 & $1-3(\varnothing 2) ; 57 \%$ \\
August 2013 & 1 and $7 ; 29 \%$ & $6 ; 14 \%$ & $3-4(\varnothing 3) ; 43 \%$ \\
September 2013 & $1-2(\varnothing 2) ; 43 \%$ & $1 ; 14 \%$ & $1 ; 14 \%$ \\
October 2013 & 1 and $18 ; 29 \%$ & 0 & 0 \\
\hline
\end{tabular}

Table 5. Intensity and prevalence of capsules with larvae Raphidascaris acus in internal organs of fish examined from May to November 2013.

\begin{tabular}{lccc}
\hline & Salvelinus fontinalis $S$ & Hybrids & Oncorhynchus mykiss \\
\hline August 2013 & $25-150(\varnothing 58) ; 100 \%$ & 15 and 35(ø25); 29\% & $15-40(\varnothing 21) ; 71 \%$ \\
September 2013 & $7-60(\varnothing 21) ; 71 \%$ & 2 and $4(\varnothing 3) ; 29 \%$ & $15-70(\varnothing 41) ; 86 \%$ \\
October 2013 & $20-140(\varnothing 80) ; 100 \%$ & $2-20(\varnothing 11) ; 71 \%$ & $60-200 ;(\varnothing 132) ; 100 \%$ \\
November 2013 & $55-200(\varnothing 145) ; 100 \%$ & $2-20(\varnothing 11) ; 71 \%$ & $15-100 ;(\varnothing 65) ; 100 \%$ \\
\hline
\end{tabular}

The relative density of the bacterial colonies of healthy fish is presented in Table 6 . Higher density of bacterial colonies was mostly identified in S. fontinalis reared in higher fish density and from origin N. In this stock Aeromonas salmonicida was also identified in 
the skin and gills of healthy fish. Yersinia ruckeri was identified only once, in the liver of a rainbow trout in November. Flavobacteria were identified mostly from the erosions on fins. We also clinically examined diseased or freshly dead fish. In $40 \%$ of examined fish $A$. salmonicida was identified in the internal organs. The highest prevalence of this bacteria was in October (in 7 out of 8 fish) and in February (in 8 out of 10 fish).

Table 6. Relative densities of bacterial colonies (1-4), calculated as means of percentage bacterial growth on agar surface $(1-25,2-50,3-75,4-100 \%)$.

\begin{tabular}{|c|c|c|c|c|c|}
\hline & & $\begin{array}{l}\text { Aeromonads } \\
\text { skin }\end{array}$ & $\begin{array}{l}\text { Aeromonads } \\
\text { gills }\end{array}$ & $\begin{array}{c}\text { Flavobacteria } \\
\text { skin }\end{array}$ & $\begin{array}{c}\text { Flavobacteria } \\
\text { gills }\end{array}$ \\
\hline S. fontinalis $\mathrm{S}$ & May 2012 & 2.2 & 1.6 & 0.4 & 0.2 \\
\hline S. fontinalis $\mathrm{N}$ & & 2.6 & 1.6 & 0 & 0 \\
\hline Hybrids $1 / 2$ & & 0.8 & 0.8 & 0.6 & 0.2 \\
\hline S. fontinalis $\mathrm{N} 1 / 2$ & & 2.0 & 1.4 & 2.0 & 1.4 \\
\hline S. fontinalis $\mathrm{S}$ & June 2012 & - & 2.14 & - & 0.43 \\
\hline S. fontinalis $\mathrm{N}$ & & - & 2.57 & - & 0.71 \\
\hline Hybrids $1 / 2$ & & - & 0.57 & - & 0.29 \\
\hline S. fontinalis N $1 / 2$ & & - & 2.0 & - & 0.43 \\
\hline S. fontinalis S & July 2012 & - & 2.14 & - & 1.86 \\
\hline S. fontinalis $\mathrm{N}$ & & - & 1.87 & - & 2.57 \\
\hline Hybrids $1 / 2$ & & - & 2.29 & - & 1.29 \\
\hline S. fontinalis N $1 / 2$ & & - & 2.29 & - & 1.57 \\
\hline S. fontinalis $\mathrm{S}$ & August 2012 & - & 1.43 & - & 1.57 \\
\hline S. fontinalis $\mathrm{N}$ & & - & 1.71 & - & 2.0 \\
\hline Hybrids $1 / 2$ & & - & 0.57 & - & 0.86 \\
\hline S. fontinalis $\mathrm{N} 1 / 2$ & & - & 1.0 & - & 0.86 \\
\hline S. fontinalis $\mathrm{S}$ & September 2012 & 1.63 & 0.88 & 0.63 & 1.0 \\
\hline S. fontinalis $\mathrm{N}$ & & 2.0 & 2.5 & 1.13 & 2.25 \\
\hline Hybrids $1 / 2$ & & 1.57 & 2.0 & 0.86 & 1.57 \\
\hline S. fontinalis N $1 / 2$ & & 1.63 & 3.14 & 0.71 & 1.63 \\
\hline S. fontinalis S & October 2012 & 0.43 & 0.43 & 1.0 & 1.0 \\
\hline S. fontinalis $\mathrm{N}$ & & $1.63($ A.s. $\times 2)$ & $2.71($ A.s. $\times 6)$ & 0.43 & 0.29 \\
\hline Hybrids $1 / 2$ & & 0.29 & 0.71 & 0.71 & 1.43 \\
\hline S. fontinalis $\mathrm{S}$ & November 2012 & 0 & 0 & 1 & 1.71 \\
\hline S. fontinalis $\mathrm{N}$ & & 0 & 0.29 & 1 & 1.43 \\
\hline Hybrids $1 / 2$ & & 0 & 0 & 0.71 & 1.43 \\
\hline S. fontinalis $\mathrm{S}$ & December 2012 & 0.38 & 0 & 0.88 & 1.5 \\
\hline S. fontinalis $\mathrm{N}$ & & $1.71($ A.s. $\times 7)$ & $2.14($ A.s. $\times 6)$ & 0.57 & 0.57 \\
\hline Hybrids $1 / 2$ & & 0.57 & 0.14 & 0.75 & 1 \\
\hline S. fontinalis $\mathrm{S}$ & January 2013 & 1.43 & 1.29 & 1.43 & 1.71 \\
\hline S. fontinalis $\mathrm{N}$ & & 1.43 & 2.43 & 1.86 & 2.29 \\
\hline Hybrids $1 / 2$ & & 1.5 & 1.71 & 1.38 & 1.86 \\
\hline S. fontinalis $\mathrm{S}$ & February 2013 & 0.75 & 0.88 & 1 & 0.63 \\
\hline Hybrids $1 / 2$ & & 0 & 0.13 & 0.5 & 0.75 \\
\hline S. fontinalis $\mathrm{S}$ & March 2013 & 0.75 & 0.25 & 0.75 & 0.38 \\
\hline Hybrids $1 / 2$ & & 0.75 & 0.88 & 1 & 1 \\
\hline
\end{tabular}

S. - Salvelinus; A.s. - Aeromonas salmonicida, number of positive samples 


\section{Discussion}

Koubková et al. (2004) described in their paper the maximum mean intensity and abundance of infection of the stone loach, Barbatula barbatula with $R$. acus larvae in a river in September. The authors speculate that the infection of stone loach by $R$. acus larvae regulates population density and the abundance of intermediate hosts downstream where natural predators are absent. The maximal intensity of larval infection was detected in October 2013 and was comparable to the stone loach from the river. The marked peak of live $R$. acus larvae abundance and mean intensity in the loach is linked to the maturation phase of the parasite (May-August) and to the termination of egg production by females in the definitive host. The parasite reaches maturity from May to June, or by midsummer at the latest (July-August) (Moravec 1970a). Evidently the full developmental cycle of $R$. acus takes place in fish breeding. The question is how can fish as a definitive host be contaminated by infective larvae? We detected the presence of pre-intermediate paratenic hosts - the Crustacea (Asellus aquaticus), Hirudinea and Diptera (larval stages of the Simulidae, Limoniidae and Chironomidae) in the system. Experimental study of individual larval stages showed that fish acted as intermediate hosts of $R$. acus, whereas invertebrates are only paratenic hosts of pre-infective second-stage larvae of the parasite (Moravec 1970b). However, the finding of fully developed, large $R$. acus third-stage larvae in naturally infected amphipods (Gammarus pulex) in Ireland (Bradley 1980) indicated that at least gammarids might act additionally, along with some vertebrates, as the true intermediate host. This was recently confirmed by Moravec (2004a) who found $G$. fossarum to be an intermediate host of $R$. acus and an important source of infection in brown trout in a small stream in the Czech Republic. The intermediate hosts of $R$. acus may not be only the numerous species of fish (loach, minnow, chub) serving as food for the definitive hosts, but also the species in which these nematodes can mature (trout, pike) (Moravec 2004b). In this way, salmonids can be both definitive and intermediate hosts. However, we found no gammarids (intermediate host) in the system, and the high prevalence of adult nematodes excludes cannibalism as a possible transfer of the infective larval stages to the definitive host. Could there be other invertebrates acting as intermediate hosts; or is it possible that the internal organs with capsules of $R$. acus of the dead trout located on the bottom are consumed by other fish, which then become definitive hosts? Interestingly, hybrids seem to be more resistant to the infective larvae of this parasite, and the lower intensity and prevalence of adults could be due to the lower mortality of fish which is connected with the low transfer of $R$. acus. Raphidascaris acus larvae have been reported as highly pathogenic parasites in the intermediate host, and mass mortality of some fish species due to heavy infection with $R$. acus larvae has been described (Bauer et al. 1977; Koubková et al. 2004).

Cipriano et al. (1992) have isolated typical $A$. salmonicida from the mucus of apparently healthy fish. The pathogenicity of mucus-isolated $A$. salmonicida has been demonstrated by Hiney (1994), who induced clinical furunculosis in disease-free brown trout by injection with a mixture of mucus and gill scrapings collected from Atlantic salmon with stressinduced furunculosis. The existence of covert furunculosis, i.e., clinically unapparent infection, has been recognized almost as long as the disease itself (Plehn 1911). Clinically unapparent infections with $A$. salmonicida could persist in fish populations. These infections could be latent, and clinical furunculosis could be precipitated in covertly infected fish populations by stress. In addition, fish with covert infections were capable of acting as carriers and could shed sufficient bacteria to transmit the infection to other fish (Hiney and Olivier 1999).

A serious problem in the monitored fish farm seems to be furunculosis of salmonid fish in all clinical forms. The most frequent incidences of $A$. salmonicida were identified in 
brook trout in the autumn. However, the growing intensity of adult $R$. acus, and mainly the capsules in the internal organs connected with pathomorphological findings seem to be a serious problem which in combination with other sublethal factors can increase mortality in fish. Therefore, eradication of this parasite is necessary in this fish breeding.

\section{Acknowledgements}

The study was supported by projects NAZV (QI91C001 and QJ 1210013). The authors would like to thank František Tichý for photographs and Charles du Parc for proofreading this paper.

\section{References}

Anacker RL, Ordal EJ 1955: Study of a bacteriophage infecting the myxobacterium Chondrococcus columnaris. J Bacteriol 70: 738-741

Bauer ON, Musselius VA, Nikolaeva VM, Strelkov YuA 1977: Ichthyopathology (in Russian). Publishing House Pischevaya Promyshlennost, Moscow, $430 \mathrm{p}$

Bradley J 1980: The roundworm genus Raphidascaris in Co. Tyrone. Irish Nat J 20: 43

Cipriano RC, Ford LA, Teska JD, Hale LE, 1992: Detection of Aeromonas salmonicida in the mucus of salmonid fishes. J Aquat Anim Health 4: 114-118

FAO 2010: The state of the world fisheries and aquaculture 2010. FAO Rome, $197 \mathrm{p}$.

Hiney MP 1994: Development and validation of detection techniques for the fish pathogen Aeromonas salmonicida. $\mathrm{PhD}$ thesis, National University of Ireland

Hiney M, Olivier G 1999: Furunculosis (Aeromonas salmonicida). In: Woo PTK and Bruno DW (Eds.): Fish Diseases and Disorders, Volume 3: Viral, Bacterial and Fungal Infections. CAB International, UK, pp. 341-426

Jokumsen A, Svendsen LM 2010: Farming of freshwater rainbow trout in Denmark. DTU Aqua Report 219-2010, $47 \mathrm{p}$.

Koubková B, Baruš V, Prokeš M, Dyková I 2004: Raphidascaris acus (Bloch, 1779) larvae infections of the stone loach, Barbatula barbatula (L.), from the River Haná, Czech Republic. J Fish Dis 27: 65-71

Martins CIM, Eding EH, Verdegem MCJ, Heinsbroek LTN, Schneider O, Blancheton JP, D'Orbcastel ER, Verreth JAJ 2010: New developments in recirculating aquaculture systems in Europe: A perspective on environmental sustainability. Aquaculture Eng 43: 83-93

Moravec F 1970a: On the life history of the nematode Raphidascaris acus (Bloch, 1779) in the natural environment of the river Bystřice, Czechoslovakia. J Fish Biol 2: 313-322

Moravec F 1970b: Studies on the development of Raphidascaris acus (Bloch, 1779) (Nematoda: Heterocheilidae). Acta Soc Zool Bohemoslov 34:33-49

Moravec F 2004a: Observations on the transmission and the seasonality of the nematode Raphidascaris acus in Salmo trutta fario in a small trout stream in North Bohemia, the Czech Republic. Helmintologia 41:91-97

Moravec F 2004b: Metazoan parasites of salmonid fishes of Europe. Academia Praha, $510 \mathrm{p}$.

Plehn M 1911: Furunculosis of Salmonids (in German). Zentral Bakteriol Parasitol Infektion Hygiene, Orig Abteil I 60: 609-624 
Plate II

Palíková M. et al.: Seasonal occurrence... pp. 201-207

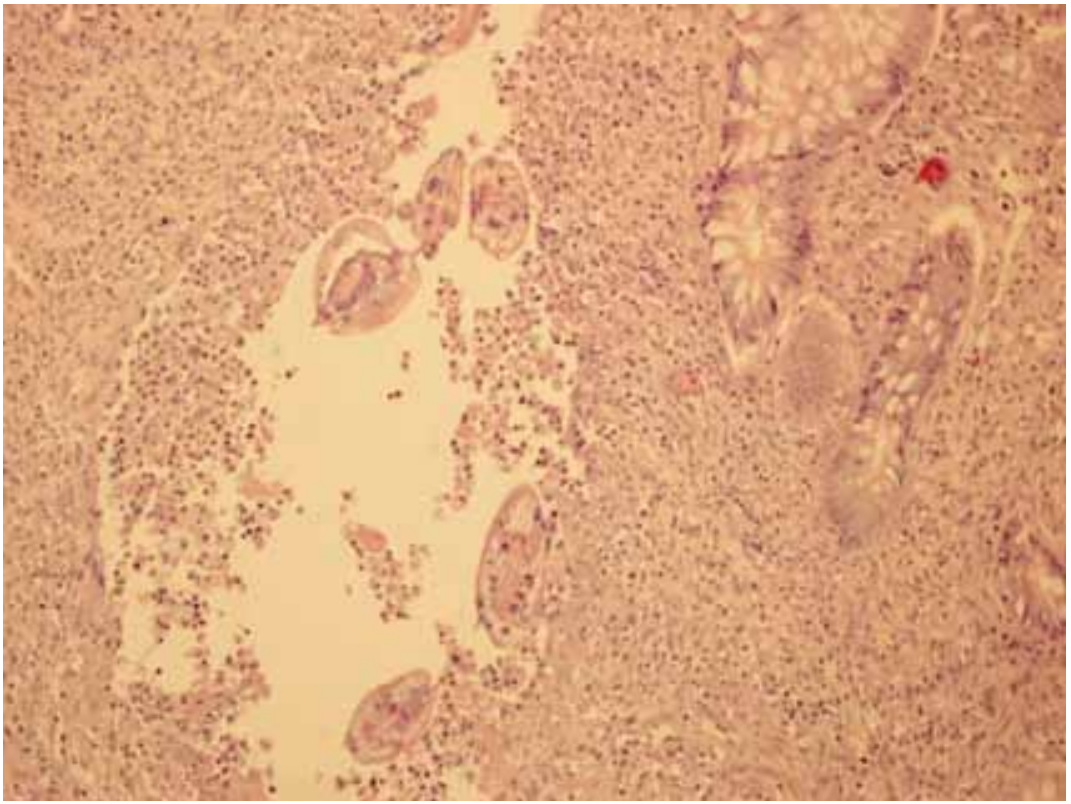

Fig. 2. Larvae of Raphidascaris acus in the intestinal wall of rainbow trout, haematoxilin-eosin staining, magnification $\times 200$



Fig. 3. Larvae of Raphidascaris acus in the migration channel in the liver parenchyma of rainbow trout, haematoxilin-eosin staining, magnification $\times 200$ 